\title{
Functional Food for the Stimulation of the Immune System Against Malaria
}

\author{
Timothy Bamgbose ${ }^{1,2}$. Anupkumar R. Anvikar ${ }^{1} \cdot$ Pilar Alberdi $^{3}$. Isa O. Abdullahi' $\cdot$ Helen I. Inabo ${ }^{2}$. \\ Mohammed Bello ${ }^{4} \cdot$ Alejandro Cabezas-Cruz ${ }^{5} \cdot$ José de la Fuente ${ }^{3,6}$ (i)
}

Accepted: 23 March 2021 / Published online: 1 April 2021

(c) The Author(s), under exclusive licence to Springer Science+Business Media, LLC, part of Springer Nature 2021

\begin{abstract}
Drug resistance has become a threat to global health, and new interventions are needed to control major infectious diseases. The composition of gut microbiota has been linked to human health and has been associated with severity of malaria. Fermented foods contribute to the community of healthy gut bacteria. Despite the studies connecting gut microbiota to the prevention of malaria transmission and severity, research on developing functional foods for the purpose of manipulating the gut microbiota for malaria control is limited. This review summarizes recent knowledge on the role of the gut microbiota in malaria prevention and treatment. This information should encourage the search for lactic acid bacteria expressing $\alpha$-Gal and those that exhibit the desired immune stimulating properties for the development of functional food and probiotics for malaria control.
\end{abstract}

Keywords Alpha gal $\cdot$ Antibody $\cdot$ Gut microbiota $\cdot$ Lactic acid bacteria $\cdot$ Plasmodium $\cdot$ Probiotics

\section{Beneficial Microbes: an Alternative for the Control of Infectious Diseases}

Infectious diseases pose a challenge to human health and modern society. In particular insects such as mosquitoes and sand, flies are considered the most important vectors of human diseases, while ticks are second to mosquitoes

José de la Fuente

jose_delafuente@yahoo.com; josedejesus.fuente@uclm.es

1 ICMR, -National Institute of Malaria Research, Sector 8, Dwarka, New Delhi, India

2 Department of Microbiology, Ahmadu Bello University, Samaru Zaria, Kaduna, Nigeria

3 SaBio, Instituto de Investigación en Recursos Cinegéticos IREC-CSIC-UCLM-JCCM, Ronda de Toledo s/n, 13005 Ciudad Real, Spain

4 Department of Veterinary Public Health and Preventive Medicine, Ahmadu Bello University, Samaru Zaria, Kaduna, Nigeria

5 UMR BIPAR, INRAE, ANSES, Ecole Nationale Vétérinaire D'Alfort, Université Paris-Est, 94700 Maisons-Alfort, France

6 Department of Veterinary Pathobiology, Center for Veterinary Health Sciences, Oklahoma State University, Stillwater, OK 74078, USA in humans and are the most important vectors of animal diseases. Mosquitoes and ticks are responsible for the transmission of pathogens that cause diseases such as malaria and dengue [1], Lyme disease, and babesiosis [2], respectively. Cholera and tuberculosis that are non-vector borne jointly contribute to the huge burden of death from infectious diseases [3]. In order to mitigate this effect, prevention and control have focused on vector control [4], antimicrobial drugs, and development of vaccines [4,5]. More recently, the role of gut microbiota for the control of infectious diseases, including viral diseases such as Covid-19, is being elucidated [6-11]. In consequence, the interest in probiotics as an alternative to antibiotics and other antimicrobial drugs is timely due also to increase in antibiotics resistance [12]. Especially, antimalarial resistance $[4,13]$ has become one of the major twenty-first century medical problems which are affecting the efforts to reduce mortality by infectious diseases $[3,8,14,15]$.

The United Nations sustainable development goal included on their second agenda the provision of safe, nutritious, and sufficient food while the third agenda focuses on promoting good health and well-being for all at all ages [16]. In the process of providing more food, functional food should also be considered. Such food, while being included to tackle hunger, will at the same time function as a means 
to deliver prophylaxis $[8,17,18]$. Traditionally fermented food contains beneficial microbe and may serve as a source of lactic acid bacteria [17, 19-22] with properties useful for immune improvement and potentially the prevention and/or treatment of malaria [6, 7, 23-25].

\section{Fermented Food as a Source of Probiotic Lactic Acid Bacteria}

Lactobacilli are the groups of bacteria widely used for probiotics [26-28] due to their functional properties [15, 29, 30]. The preference for lactobacilli from fermented food is associated with their ability to multiply at low $\mathrm{pH}[28,31]$, survive the intestinal bile [27, 32, 33], compete for adhesion site [34-36], out-compete and limit the growth of pathogenic bacteria [32, 37, 38], and also regulate the immune system $[8,15,29,39,40]$.

The ability to modulate both innate and adaptive immune responses is one of the major reasons lactobacilli are applied in the field of probiotics [15]. It has been documented that lactobacilli produces antimicrobial substances [37] and can interact with intestinal epithelial cells (IECs) and dendritic cells (DCs) preventing the spread of pathogens [41-43], thus providing chemical and physical barriers to enhance innate immunity [15]. More so, they have been found to activate antigen-specific response, thereby improving both innate and adaptive immune responses [29, 41, 44].

Interestingly, different strains of the same species may express different functional properties, for example, lactobacillus alone having over 255 species is a specific example $[42,45,46]$. This suggests that probiotic bacteria are an unlimited source for desirable therapeutic or beneficial properties. Therefore, for their documented probiotic property and particularly their ability to stimulate immunological response, there should be a renewed search for specific strains for functional food development $[44,47,48]$ applicable for the prevention and treatment of malaria.

\section{Humoral Immunity to Malaria}

Malaria, caused by a protozoan parasite of the genus Plasmodium, is a vector-borne disease transmitted by female Anopheles mosquitoes during blood feeding. Malaria infected over 218 million people and killed 405,000 in 2018 [49]. This disease is highly prevalent in poor tropical and subtropical areas of the world and is considered the leading cause of illness and death in endemic countries [50,51]. The clinical presentations resulting from Plasmodium infections range from asymptomatic to severe malaria, which is associated with cerebral malaria, severe anemia and respiratory distress $[52,53]$. However, the factors that determine malaria severity remain poorly understood, even though the levels of parasitemia are the most regarded determinant [24, 53, 99].

After several exposures to mosquito bites, adult individuals tend to remain asymptomatic which might be due to antibodies developed against the sporozoite, liver-stage, blood-stage, and the sexual-stage Plasmodium antigens over time resulting in naturally acquired immunity $[52,54,55]$ as evident in asymptomatic infected person [56]. The antibody developed might not affect the malaria parasite directly but can interfere with the Plasmodium life cycle at different stages such as blocking the entrance of sporozoite into liver cells, preventing erythrocyte invasion and even limiting transmission in cases of those directed at sexual stage. Further, the immune system plays a vital role in the host by removing parasite at the early stage of infection through cytokines generated and the immune response also regulates the adaptive immunity to prevent excessive production of inflammatory cytokines that are harmful [57-60]. Hence, considering how vital immune response is in the fight against malaria [57, 61], with the increasing rate of drug resistance $[62,63]$ coupled with low efficacy of pre-existing drugs [64] and vaccine [5], it is important to have a multifaceted approach to stimulating the body natural defense against Plasmodium infection and a case for microbiota control can be made (Table 1) [7, 53].

\section{Microbiota-induced Protection Against Plasmodium}

To curtail the spread of malaria, aside from vector control, transmission-blocking interventions [65-67] are also an area of considerable importance. This has led to the study of the interactions between microbes in the midgut of mosquito revealing the anti-Plasmodium effect of mosquito microbiota that reduces the establishment of Plasmodium in the mosquito gut, thereby limiting the ability of the vector to transmit the pathogen $[68,69]$. Further studies on the gut microbiome of mosquito using different DNA sequencing technologies have identified several midgut-associated bacteria such as Enterobacter, Pseudomonas, Chromobacterium, and Serratia that were implicated in preventing Plasmodium colonization in vector mosquito $[1,69,70]$.

Emphasis had been on mosquito gut because both the parasite and the natural microbiota share this body compartment [71]. Thus, it has been established that bacteria in the midgut do have an inhibitory effect on Plasmodium, using mechanisms such as the production of reactive oxygen intermediates with anti-parasitic properties, triggering the innate immune system to produce antimicrobial molecules and also physically preventing the Plasmodium from having contact with the mosquito epithelium [70, 71]. 


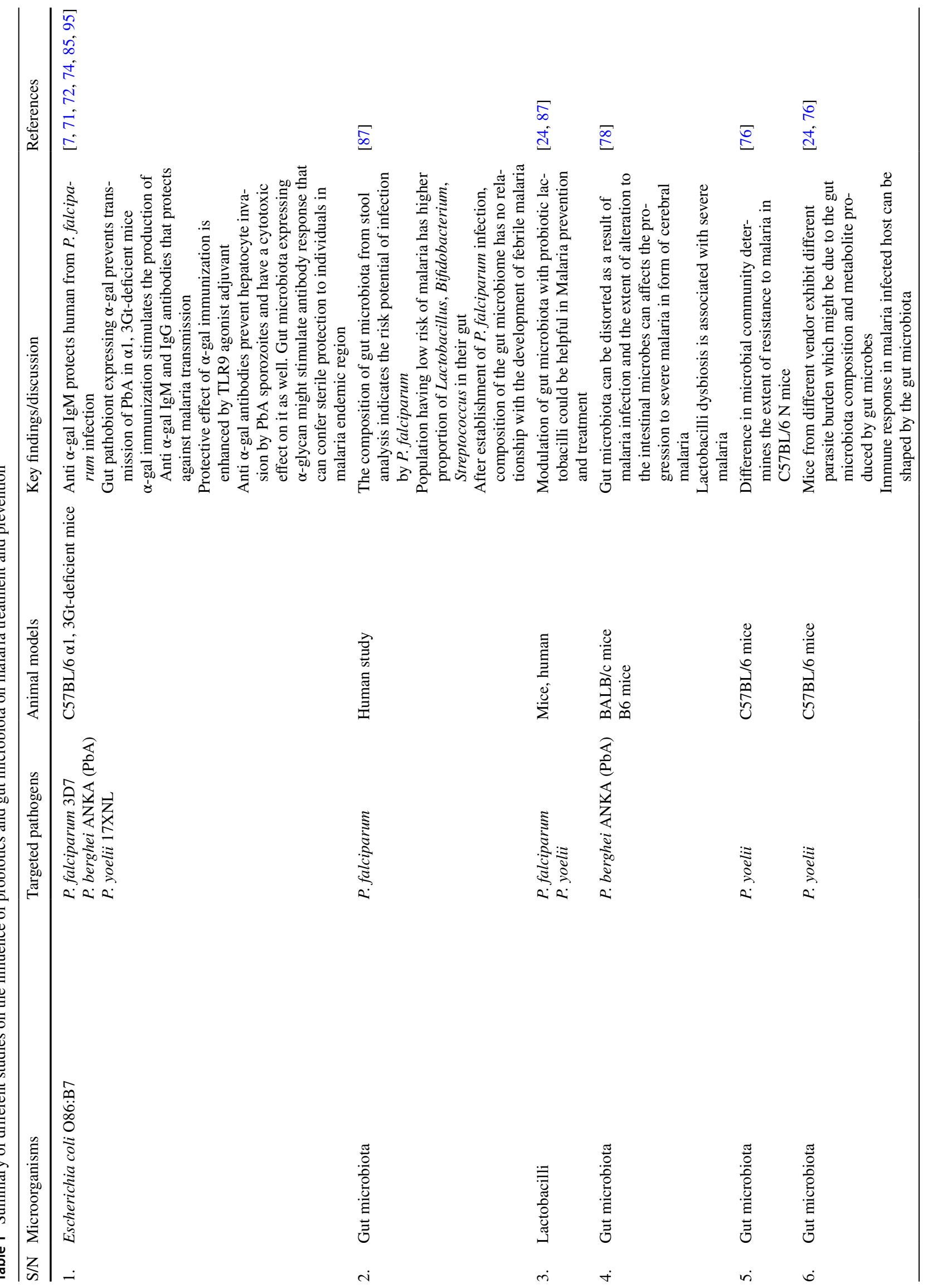




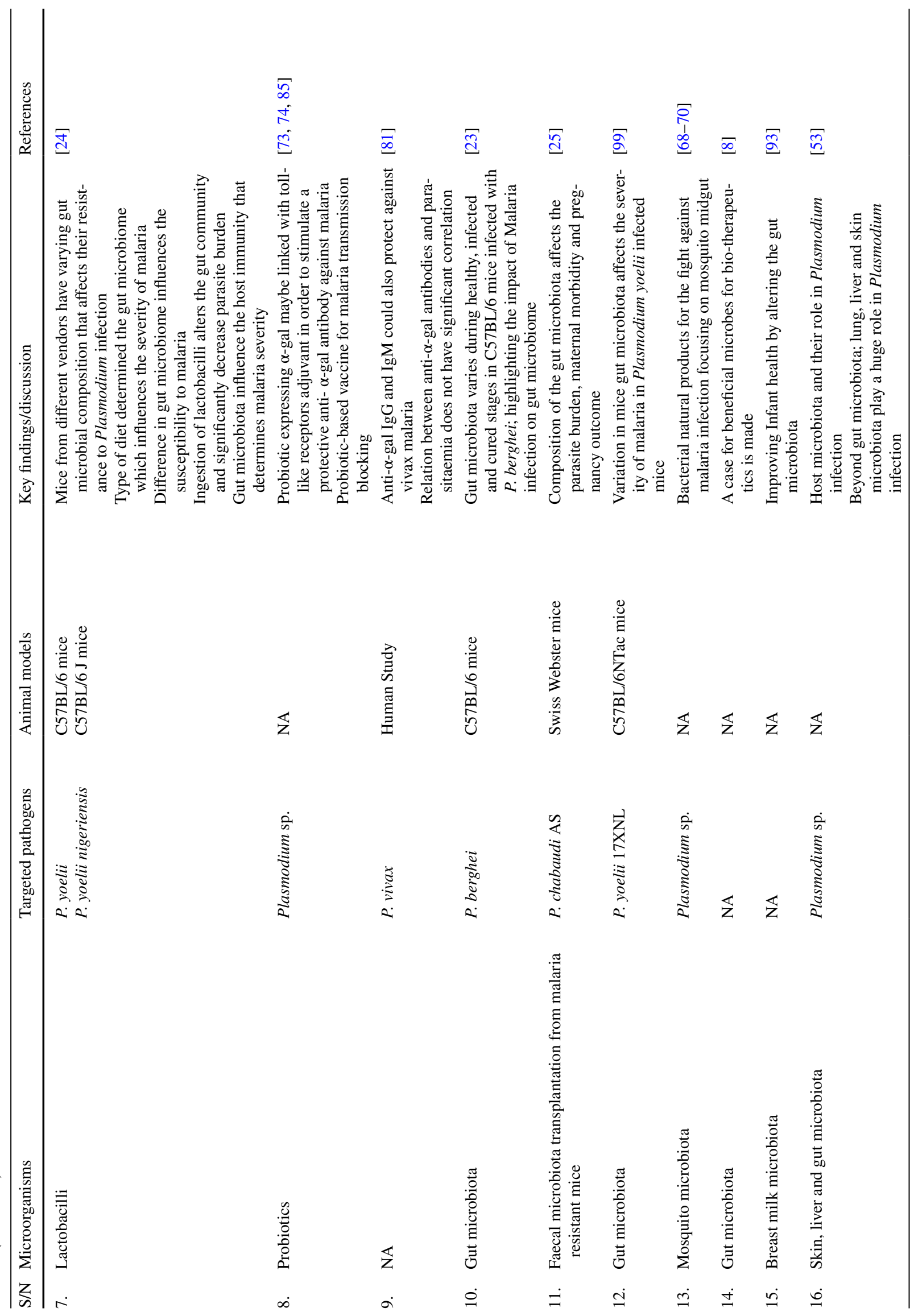




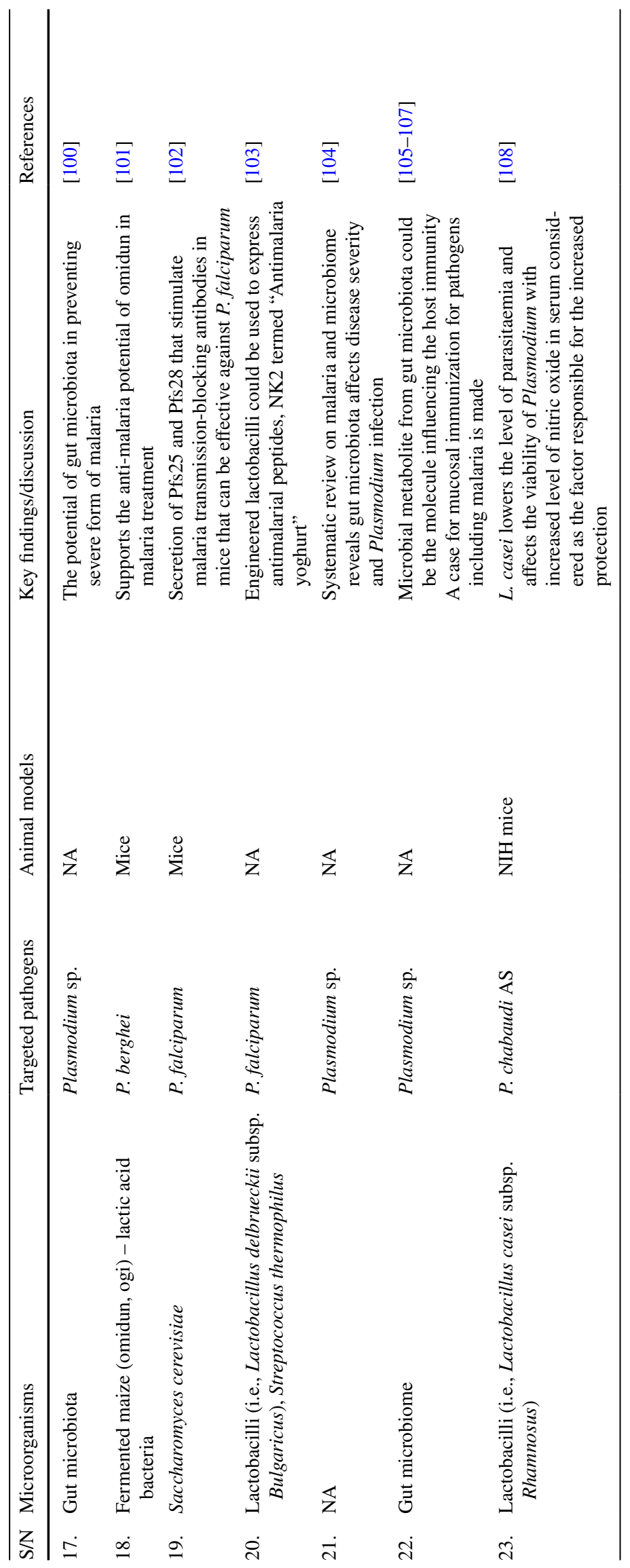


Consequently, the inhibitory property exhibited by the midgut commensal bacteria points to the transmissionblocking potential mosquito gut microbiota has on parasitic infection [71]. However, these studies focused on the mosquito midgut microbiota and are limited to the vector and their ability to transmit the parasite to human host [70]. In human, the gut microbiota can regulate the immune system either in blocking transmission (from skin to liver stage) by limiting incidences [65, 72-74] or by upregulating the immune system (Table 2) to reduce the severity of malaria in case of disease establishment (Fig. 1) [24, 25, 75].

\section{Vertebrate Host Microbiota Protects Against Plasmodium Infection}

Most recent research that delved into the role of probiotics and gut microbiota for the control of parasites has tried to answer the question of how the gut microbiota can be effective in parasite control; however, the exact mechanisms of protection are far from being completely understood [23, 76]. One of the earliest investigations studied the protective role of probiotic lactobacilli (i.e., Lactobacillus casei ATCC 7469) in mice infected with Plasmodium chabaudi strain AS in which it was observed that parasitemia of infected mice was lower when the mice were treated with the probiotic [77]. It was suggested that the increase in nitric oxide (NO) concentration in the serum of experimentally infected mice fed with $L$. casei was the factor responsible for the increased protection [77]. This submission was based on previous reports on the protective role of NO in severe falciparum malaria using S-nitroso-acetyl-penicillamine (SNAP), a NO producer that has an antimalarial effect on Plasmodium falciparum by preventing cytoadherence [109], as well as a cytotoxic and cytostatic effect observed in $P$. falciparum asexual stage with a significant effect on the later asexual stage than the trophozoites (ring) stage. The same effect was also observed in P. chabaudi AS and Plasmodium berghei

Table 2 Immune factors regulated by gut microbiota and their function

\begin{tabular}{|c|c|c|c|c|}
\hline $\mathrm{S} / \mathrm{N}$ & Immunological factors & Function & Plasmodium life cycle & References \\
\hline 1. & $\begin{array}{l}\text { Anti } \alpha \text {-gal IgM and } \operatorname{IgG}(\operatorname{IgG} 2 b \text {, } \\
\text { IgG3) }\end{array}$ & $\begin{array}{l}\text { Binds to Plasmodium sporozoite and } \\
\text { initiate classical complement path- } \\
\text { way thereby inhibiting hepatocyte } \\
\text { invasion resulting in the blocking of } \\
\text { sporozoite transmission }\end{array}$ & Skin & {$[24,72-74,80,85]$} \\
\hline 2. & $\mathrm{CD} 8^{+}, \mathrm{CD}^{+}{ }^{+}, \mathrm{T}$ cells & $\begin{array}{l}\text { Initiate sterilizing immunity that is } \\
\text { not naturally acquired but relies } \\
\text { solely on this adaptive immune } \\
\text { factor. They are also antigen specific } \\
\text { and target the intracellular stages of } \\
\text { infection }\end{array}$ & Skin and liver & $\begin{array}{l}{[5,7,24,52,55,56,58,60,66} \\
\quad 75]\end{array}$ \\
\hline 3. & IFN- $\gamma$, TNF, IL-2 & $\begin{array}{l}\text { Protection against sporozoite and } \\
\text { blood-stage antigen. Also, involved } \\
\text { in the early stage by inhibiting } \\
\text { parasite replication }\end{array}$ & Liver & {$[52,55,58,60,66,75,111]$} \\
\hline 4. & NK, NKT, $\gamma \delta \mathrm{T}$ cells, Macrophages & $\begin{array}{l}\text { Stimulate the production of nitric } \\
\text { oxide, and nitric oxide synthase that } \\
\text { prevent cytoadherence and resetting } \\
\text { of infected red blood cells (RBCs) } \\
\text { to uninfected RBCs thereby prevent- } \\
\text { ing parasite replication }\end{array}$ & Blood & {$[52,56,60,106,108-111]$} \\
\hline 5. & IL-1 $\beta$, IL-6, IL-8, IL-12 & $\begin{array}{l}\text { Pro-inflammatory cytokines that } \\
\text { cause fever and severe form of } \\
\text { malaria that can be downregulated } \\
\text { by gut microbiota }\end{array}$ & Blood & {$[17,52,58,60,90]$} \\
\hline 6. & TGF- $\beta$, IL-10 & $\begin{array}{l}\text { Anti-inflammatory cytokines } \\
\text { (regulatory cytokines) that reduce } \\
\text { parasitaemia }\end{array}$ & Blood & {$[52,55,58,60,106,111]$} \\
\hline 7. & Treg, DCs & $\begin{array}{l}\text { Balancing of the immune system and } \\
\text { presents sporozoite to the T cells } \\
\text { that help in the activation of B cells } \\
\text { for parasite clearance }\end{array}$ & Blood & {$[24,52,106,111]$} \\
\hline
\end{tabular}

$N K$ natural killer, $N K T$ natural killer T cells, $I F N-\gamma$ interferon-gamma, $T N F$ tumor necrosis factor, $I L$ interleukins, $T G F$ transforming growth factor, $D C$ dendritic cells 


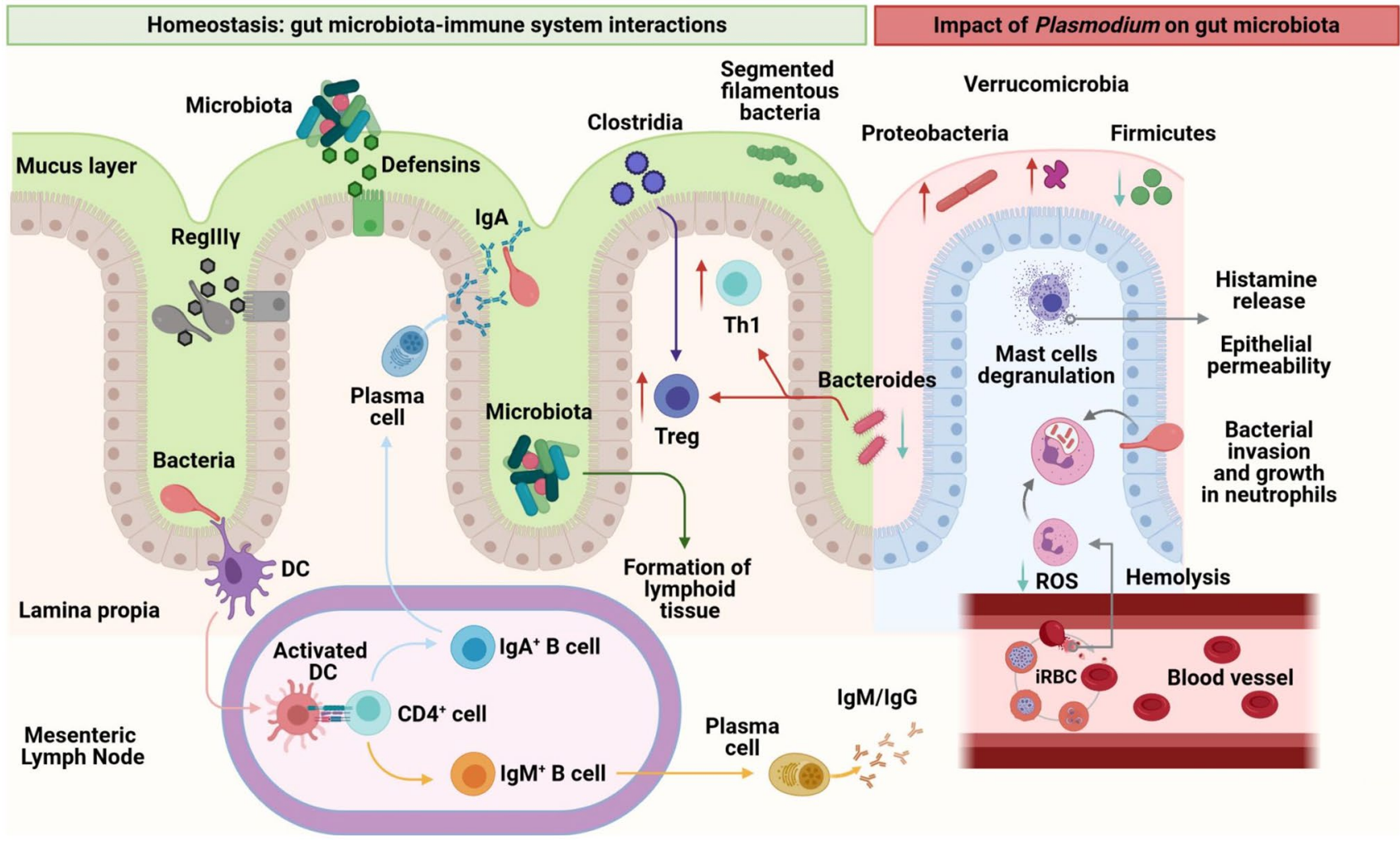

Fig. 1 Disruption of homeostatic gut microbiota-immune system interactions by Plasmodium infection. In a healthy status, several immune effectors function together to regulate bacteria-epithelial contacts and maintain gut homeostasis. This includes the mucus layer, epithelial antibacterial proteins (e.g., defensins and RegIII $\gamma$ ), and $\operatorname{IgA}$ secreted by the lamina propria plasma cells. Dendritic cells (DC) recognize bacterial antigens, activate and migrate to lymph nodes where antigen presentation to $\mathrm{CD} 4^{+}$cells occur. Activate $\mathrm{CD} 4{ }^{+}$cells stimulate $\operatorname{Ig} \mathrm{A}+$ and $\mathrm{IgM}+\mathrm{B}$ cells, which in turn differentiate to plasma cells that produce IgA (secreted to the intestinal lumen) and IgM (that enters the blood circulation). Specific members of the

KSP11 in an animal model, showing an inhibitory effect to the asexual erythrocytic stage [110]. Most importantly is that the effect of $\mathrm{NO}$ is more significant in human malaria than rodent malaria. Hence, a probiotic organism that can increase the amount of NO produced in the blood will be a good candidate for modulating the human gut microbiota for malaria treatment (Fig. 2) [77, 108-110]. Furthermore, when C57BL/6 and BALB/c mice were infected with $P$. berghei strain ANKA, it was observed that the degree of malaria severity in terms of cerebral malaria and intestinal pathology varied with the composition of the host gut microbiota [78].

Likewise, Fan et al. [23] reported that lactobacilli were the dominant microbes in healthy C57BL/6 mice infected with $P$. berghei ANKA while in a separate study where C57BL/6 mice were infected with $P$. yoelii, the abundant presence of lactobacilli reduced the severity of malaria observed by the lower parasite burden as compared to naïve mice [24]. Remarkably, in another investigation in which microbiota such as Clostridia and Bacteroides stimulate the development and proliferation of Treg and Th1 cells. Malaria promotes the activation and degranulation of mast cells which increases epithelial permeability and bacteria invasion. Plasmodium infection of red blood cells (iRBC) also produces hemolysis that by decreasing reactive oxygen species (ROS) production by neutrophils increase the growth of invading bacteria within these polymorphonuclear leukocytes. These changes modulate human microbiota by increasing some taxa such as Proteobacteria and Verrucomicrobia and decreasing other taxa such as Bacteroides and Firmicutes. Figure created with BioRender.com

C57BL/6 mice were purchased from a different vendor and infected with $P$. yoelii, the difference in the gut microbiota determined their resistance or susceptibility to malaria [76], thus adding credence to the role of the gut microbiota in malaria severity.

Another microbiota induced protection was observed by Yilmaz et al. [72] in the mouse GalKO model with the knocked-out gene coding for the galactosyltransferase involved in the synthesis of the glycan Gala1-3Galb14GlcNAc-R ( $\alpha-\mathrm{Gal})$. Mice GalKO were fed with a pathobiont Escherichia coli O86:B7 that expresses a high level of $\alpha-G a l$, a glycan found on the surface of Plasmodium sporozoites. The glycan stimulated B cells to produce anti$\alpha-\mathrm{Gal} \operatorname{IgM}$ and IgG antibodies that block the transmission of sporozoites from the skin to the liver stage and produces sterilizing immunity in mice. The same effect was derived through immunization with $\alpha$-Gal antigen [72]. A similar protective effect of anti- $\alpha-\mathrm{Gal} \operatorname{IgM}$ and $\operatorname{IgG}$ was found in 
Fig. 2 Elucidating the specific stage of the Plasmodium cycle that a probiotic can exert an inhibitory effect. (1) The $\alpha$-Gal-expressing microbes cause the stimulation of B cells to produce anti- $\alpha$-gal $\operatorname{IgM}$ and IgG. The $\alpha$-gal glycan sequence is similar to the one present on Plasmodium sporozoite surface; thus, anti- $\alpha$-gal antibody generated has been reported to bring about sterile immunity by blocking the transmission of Plasmodium sporozoite from skin to liver stage through complement-mediated lysis of sporozoites in the skin. (2) Lactobacillus casei ATCC 7469 , a probiotic, has been studied to bring about reduced level of parasitaemia and lowers the viability of Plasmodium by increasing the serum concentration of nitric oxide affecting the erythrocytic stage. Abbreviation: $\alpha$-Gal, galactose- $\alpha-1,3-$ galactose. Figure created with BioRender.com

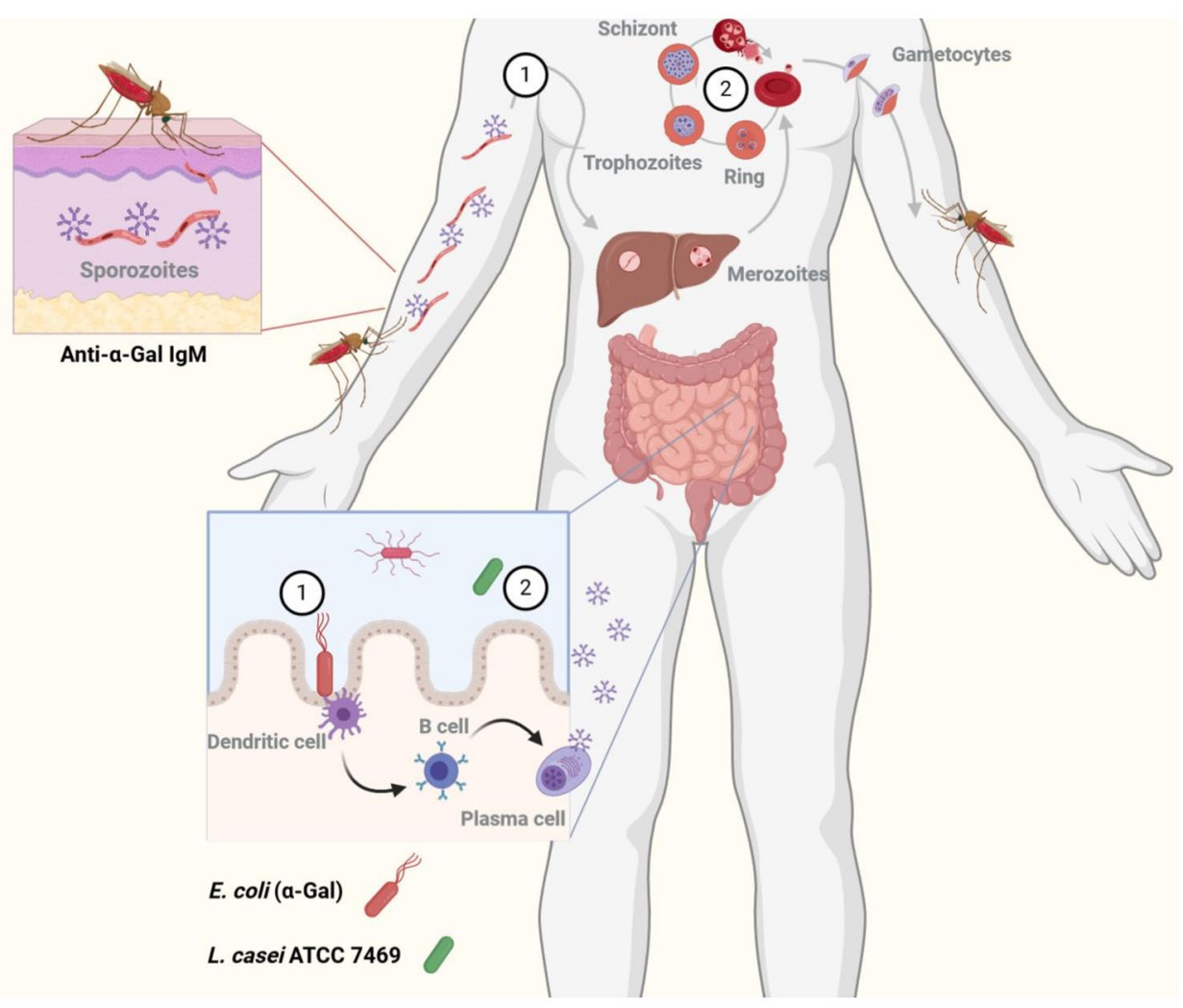

human exposed to Plasmodium-infected mosquito [72, 79]. Humans have evolutionarily lost the ability to synthesize $\alpha$-Gal resulting in the immune system releasing antibodies specific to this carbohydrate [80-82]. It has been reported that all non-immunocompromised persons have the ability to produce antibodies against $\alpha$-Gal [83], which makes up approximately $1 \%$ of $\mathrm{IgG}$ and $5 \%$ of $\operatorname{IgM}$ circulating immunoglobulins [84]. Thus, the amounts of anti- $\alpha-G a 1$ IgM/IgG observed in non-infected individuals and those living in malaria-endemic areas such as Mali and Senegal are protecting them from malaria parasite $[72,79,81]$. Hence, populating the gut with probiotics that expresses $\alpha$-Gal on their cell surface might be effective in stifling the transmission rate by boosting the anti- $\alpha$-Gal immune response mediating the lower incidences of malaria (Fig. 2) [7, 71, 74, 85]. At the same time, $\alpha-G a l$ has been proposed for vaccine development to target Plasmodium parasites at different stages [56, $65,74,85,86]$.

However, the most compelling argument for the role of microbiota in malaria parasite infection in humans is from the study of Yooseph et al. [87] that investigated the relationship between the gut microbiota composition and P. falciparum infection in malaria-endemic areas. It was observed from the analysis of stool microbiota that the presence of a higher number of Streptococcus and Bifidobacterium correlates with a lower risk of $P$. falciparum infection although without a relationship with febrile malaria [87].
Consequently, the use of probiotics for functional food development as a dietary supplement would be a good strategy for more investigation in order to find ways to prevent malaria incidence and also reduce the severity in case of infection [73, 74].

\section{Developing Functional Foods to Stimulate Anti-a-gal Immune Response, the Search Continues}

Ellie Metchnikoff, a Russian scientist, came up with the hypothesis that some microorganisms are beneficial and improve human health by observing the Bulgarians that consume fermented milk in large quantities, which he assumed as the sole factor for their long life and good health $[17,88$, 89]. This hypothesis was termed as "theory of longevity" as he observed the effect that these bacteria in the human intestine have on general well-being, thus serving as an upshot for further study that investigated the preventive role of the gut microbiota in diseases [90, 91]. Later on, Lilly and Stillwell used the term probiotics signifying "prolife" [31, 42], a term that has undergone several definitions but currently is defined as viable, non-pathogenic microorganisms that, when ingested in adequate amounts, are able to reach and establish in the gut to confer health benefits to the host [44]. 
Furthermore, in the works of Maegraith et al. [92] in which different groups of rats and mice were infected with $P$. berghei to induce blood-stage malaria and were fed with a normal diet, cow milk, reconstituted Oster milk, and reconstituted Australian dried milk, it was observed that as opposed to the normal diet, the milk diet contains some dietary factors that suppressed the development of Plasmodium as prevention of death was observed in some of the treated animals. It was concluded that some attention should be paid to the effect of milk in human malaria as breastfed children rarely have severe malaria while acknowledging that at the same period, another researcher opined that there is a factor in milk that has a protective role against some viral infections [92, 93].

Subsequently, in the last decade, there is a renewed interest in what this factor could be. At first, Lokki et al. [94] suggested that lactase persistence gene could be responsible for the increasing resistance to malaria among the Fulani tribe of West Africa but could not establish a statistical significance with it. Nevertheless, from the study, they considered that since the Fulani feed a lot on milk product, there must be a factor in milk that is responsible for the observed resistance. Hence, the study maintained that the nutrient element in milk, immunomodulating components, and milk-induced para-aminobenzoic acid (PABA) deficiency might be the reason for the protection against malaria [94].

However, Maegraith et al. [92] and Lokki et al. [94] did not consider the role of microbes in their study [93], a factor that Yilmaz et al. [72] considered when E. coli O86:B7 effect on malaria severity was studied. The bacteria enabled immune protection against malaria infections in the experimental mice, establishing a possible human gut microbiota-driven immunity against malaria by limiting infection incidence [71]. Considering that $E$. coli $\mathrm{O} 86$ :B7 is not naturally associated with foods and the pathogenic strains of the specie exist, it is not overtly suitable as a candidate for probiotics [73].

Thereafter, lactobacilli with documented probiotics properties were used to formulate yoghurt that was fed to experimental mice infected with Plasmodium, resulting in an antecedent decrease in parasite burden [24]. Besides, when cecal content of malaria resistant mice was transplanted to susceptible mice, they developed resistance to severe malaria and the afterwards genomic analysis of the gut microbiota revealed the abundant presence of lactobacilli establishing the role of the microbiota in the severity of malaria [24, $25,76,99]$. Moreover, in comparison between the works of Maegraith et al. [92] and Villarino et al. [24] despite the difference in the research timeline, it can be concluded that the answer to the unknown factor in milk that suppresses the development of Plasmodium has to do with the milk microbiota [93]. Additionally, the transplantation of fecal microbiota that confers malaria resistance to pregnant mice that resulted in lower parasite burden prevented malaria anemia and enhanced the pregnancy outcome support the importance of gut microbiota composition in malaria severity [25].

Considering the established beneficial effect of the gut microbiota as it relates to human health (Table 1), particularly to malaria prevention and treatment, there is need to bio prospect for lactobacilli with the needed property that can be developed as a functional food. A functional food containing probiotic organisms that can protect against parasite transmission and/or reduce the severity by stimulating immune response (Table 2) will be desirable for modulating the gut microbiota [40, 53, 91, 95-98].

The understanding of how gut microbiota exerts a positive effect on Plasmodium infection is still not clear, and all shreds of evidence are mainly from an animal model using rodent-malaria studies. It is also worthy of note that the gut community of mice differ considerably from humans as well as between mice having different diets and breeding environment [23-25, 99]. Notwithstanding, the few human studies on the correlation between gut microbiota composition and malaria severity is a pointer to the fact that the modulation of the gut microbiota with probiotics or functional food could be an alternate means in malaria management (Table 1). As the case of resistance to antimalarial keeps growing coupled with the fact that vaccine development is still at the early stage, future research can focus on how modulation of the gut microbiota can aide vaccination for the stimulation of specific immune response against malaria.

\section{Concluding Remarks and Future Perspectives}

Gut microbiota has a great impact in modulating immune response $[24,76]$, implicated in parasite clearance [25, $76,77]$ and a potential tool for vaccine development $[74$, 85, 105-107]. Considering all evidence from the role of gut microbiota in malaria severity, the time is ripe for an intensified study on probiotics for the control of malaria and prevention of its severe form in which development of functional food is vital. The findings that have supported the impact of gut microbiota with respect to their protective role in malaria pathogenesis need to be scaled up for its intended benefits. Development of functional food containing probiotics from fermented foods with desired properties or genetically modified bacterial strains for the purpose of manipulating the gut microbiota is important to advance the control of malaria and other infectious diseases.

Despite the advances and potential impact that vaccines represent for the prevention and control of infectious diseases, interventions boosting the immune response to $\alpha$-Gal with a broader and not pathogen-specific immunity may contribute not only to the control of malaria but also 
to other diseases. Probiotic-based formulations with abundant commensal bacteria of the gut and lung microbiota with high $\alpha$-Gal content may be developed for the prevention and control of malaria and other major infectious diseases affecting humans worldwide (Fig. 2). One of the major challenges of vaccination campaigns in poor regions with a high prevalence of infectious diseases is the distribution and administration of the vaccine. The possibility of developing probiotics that can be delivered in stable formulations such as a yoghurt or food supplements will make these interventions easier to distribute and administer. These formulations have a low production cost and are easy to administer with a major impact in regions with limited access to health services.

Future research should address the mechanisms mediated by $\alpha-G a l$ immunization; the characterization of gut and lung microbiota including $\alpha-G a l$ content in infected, exposed, and healthy individuals; and the identification of commensal bacteria with $\alpha$-Gal modifications for the development and evaluation of probiotic-based formulations. Even though the mechanism of action is still a study in process, the usage of probiotics to stimulate immune system towards malaria disease holds a significant prospect. Thus, there should also be increase interest in clinical study beyond field observation while more funding should be made available for meticulous study of fermented foods and formulation of functional foods for the same purpose.

Acknowledgements The World Academy of Science, Italy, and the Department of Biotechnology, India, are acknowledged. The authors would like to thank Toba Adeyinka for assisting in image design.

Funding Research on $\alpha$-Gal has been supported by the Consejería de Educación, Cultura y Deportes, JCCM, Spain, projects CCM17PIC-036 (SBPLY/17/180501/000185).

\section{Declarations}

Conflict of Interest The authors declare no competing interests.

\section{References}

1. Short SM, Bahia AC, Mlambo G, Dong Y, Saraiva RG, Ramirez JL, Tripathi A, Dimopoulos G, Kang S (2014) Chromobacterium Csp_P reduces malaria and dengue infection in vector mosquitoes and has entomopathogenic and in vitro anti-pathogen activities. PLoS Pathog 10(10):e1004398. https://doi.org/10.1371/ journal.ppat.1004398

2. Wikel SK (2018) Ticks and tick-borne infections: complex ecology, agents, and host interactions. Vet Sci 5(2):60. https:// doi.org/10.3390/vetsci5020060

3. Waldvogel FA (2004) Infectious diseases in the 21st century: old challenges and new opportunities. Int J Infect Dis 8(1):512. https://doi.org/10.1016/j.ijid.2003.01.001
4. Bloland PB (2001) Drug resistance in malaria. A background document for the WHO global strategy for containment of antimicrobial resistance. WHO/CDS/CSR/DRS/2001.4

5. Frimpong A, Kusi KA, Ofori MF, Ndifon W (2018) Novel strategies for malaria vaccine design. Front Immunol 9(11):2769. https://doi.org/10.3389/fimmu.2018.02769

6. Kamada N, Chen GY, Inohara N, Núñez G (2013) Control of pathogens and pathobionts by the gut microbiota. Nat Immunol 14(7):685-690. https://doi.org/10.1038/ni.2608

7. Soares MP, Yilmaz B (2016) Microbiota control of malaria transmission. Trends Parasitol 32(2):120-130. https://doi.org/ 10.1016/j.pt.2015.11.004

8. LeBegue CE, Love BL, Wyatt MD (2020) Microbes as drugs: the potential of pharmabiotics. Pharmacotherapy 40(2):102-106. https://doi.org/10.1002/phar.2357

9. de la Fuente J (2020) The exquisite corpse for the advance of science. Arts et Sciences 4(3). https://doi.org/10.21494/iste.op. 2020.0506

10. Mak JWY, Chan FKL, Ng SC (2020) Probiotics and COVID-19: one size does not fit all. Lancet Gastroentero Hepatol 5(7):644645. https://doi.org/10.1016/S2468-1253(20)30122-9

11. Budhwar S, Sethi K, Chakraborty M (2020) A rapid advice guideline for the prevention of novel coronavirus through nutritional intervention. Curr Nutr Rep 9(3):119-128. https://doi.org/ 10.1007/s13668-020-00325-1

12. Czaplewski L, Bax R, Clokie M, Dawson M, Fairhead H, Fischetti VA, Foster S, Gilmore BF, Hancock REW, Harper D et al (2016) Alternatives to antibiotics-a pipeline portfolio review. Lancet Infect Dis 16(2):239-251. https://doi.org/10.1016/S1473-3099(15) 00466-1

13. Ringwald P, Vestergaard LS (2007) Responding to the challenge of antimalarial drug resistance by routine monitoring to update national malaria treatment policies. Am J Trop Med Hyg 77(6_ Suppl):153-159. https://doi.org/10.4269/ajtmh.2007.77.153

14. Murray CJL, Rosenfeld LC, Lim SS, Andrews KG, Foreman KJ, Haring D, Fullman N, Naghavi M, Lozano R, Lopez AD (2012) Global malaria mortality between 1980 and 2010: a systematic analysis. Lancet 379(9814):413-431. https://doi.org/10.1016/ S0140-6736(12)60034-8

15. Vieco-Saiz N, Belguesmia Y, Raspoet R, Auclair E, Gancel F, Kempf I, Drider D (2019) Benefits and inputs from lactic acid bacteria and their bacteriocins as alternatives to antibiotic growth promoters during food-animal production. Front Microbiol 10:57. https://doi.org/10.3389/fmicb.2019.00057

16. United Nations (2015) Sustainable development goals. Available: https://sustainabledevelopment.un.org/?menu=1300 Retrived 10th of April 2020. [Accessed: 10-Apr-2020]

17. Franz CM, Huch AP, Mathara M, Abriouel JM, Benomar H, Reid N, Galvez GA, Holzapfel WH (2014) African fermented foods and probiotics. Int J Food Microbiol 190:84-96. https://doi.org/ 10.1016/j.ijfoodmicro.2014.08.033

18. Karmali N, Le T (2020) Equal access to beneficial microbes : a tool for reduced malnutrition. Health Equity Access 1(5):53-55. journals.mcmaster.ca/CHAR

19. Olasupo NA, Olukoya DK, Odunfa SA (1997) Identification of Lactobacillus species associated with selected African fermented foods. Zeitschrift fur Naturforsch Sect C - J Biosci 52:105-108

20. Oyewole OB (1997) Lactic fermented foods in Africa and their benefits. Food Control 8(5-6):289-297. https://doi.org/10.1016/ S0956-7135(97)00075-3

21. Bayili GR, Johansen P, Nielsen DS, Sawadogo-Lingani H, Ouedraogo GA, Diawara B, Jespersen L (2019) Identification of the predominant microbiota during production of lait caillé, a spontaneously fermented milk product made in Burkina Faso. World J Microb Biot 35(7):100. https://doi.org/10.1007/ s11274-019-2672-3 
22. Diaz M, Sayavedra L, Atter A, Mayer MJ, Saha S, Amoa-Awua W, Narbad A (2020) Lactobacillus garii sp. nov., isolated from a fermented cassava product. Int J of Syst Evol Microbiol 70:3012-3017. https://doi.org/10.1099/ijsem.0.004121

23. Zhi-gang F, Li X, Hai-yi Fu, Zhou L-M, Fei-li G, Fang M (2019) Gut microbiota reconstruction following host infection with blood-stage Plasmodium berghei ANKA strain in a murine model. Curr Med Sci 39(6):883-889. https://doi.org/ 10.1007/s11596-019-2119-y

24. Villarino NF, LeCleir GR, Denny JE, Dearth SP, Harding CL, Sloan SS, Gribble JL, Campagna SR, Wilhelm SW, Schmidt NW (2016) Composition of the gut microbiota modulates the severity of malaria. PNAS USA 113(8):2235-2240. https://doi. org/10.1073/pnas.1504887113

25. Morffy-Smith CD, Gong M, Andrew AK, Russ BN, Ge Y, Zadeh M, Cooper CA, Mohamadzadeh M, Moore JM (2019) Composition of the gut microbiota transcends genetic determinants of malaria infection severity and influences pregnancy outcome. EBioMedicine 44:639-655. https://doi.org/10.1016/j. ebiom.2019.05.052

26. König H, Fröhlich J (2016) Lactic acid bacteria, general characteristics, food preservation and health benefits. in Biology of microorganisms on grapes, in must and in wine. J Fröhlich ed (Springer, Cham), pp. 3-41. https://doi.org/10.1007/ 978-3-319-60021-5_1

27. Olatunde OO, Obadina AO, Omemu AM, Oyewole OB, Olugbile A, Olukomaiya OO (2018) Screening and molecular identification of potential probiotic lactic acid bacteria in effluents generated during ogi production. Ann Microbiol 68(7):433-443. https://doi. org/10.1007/s13213-018-1348-9

28. Padmavathi T, Bhargavi R, Priyanka PR, Niranjan NR, Pavitra PV, Tallapragada P, Rayavarapu B, Rao PP, Ranganath NN (2018) Screening of potential probiotic lactic acid bacteria and production of amylase and its partial purification. J Genet Eng Biotechnol 16(2):357-362. https://doi.org/10.1016/j.jgeb.2018.03.005

29. Cano-Garrido O, Seras-Franzoso J, Garcia-Fruitós E (2015) Lactic acid bacteria: reviewing the potential of a promising delivery live vector for biomedical purposes. Microb Cell Fact 14(1):137. https://doi.org/10.1186/s12934-015-0313-6

30. Zielińska D, Kolozyn-Krajewska D, Laranjo M (2018) Foodorigin lactic acid bacteria may exhibit probiotic properties: review. Biomed Res Int 2018:5063185. https://doi.org/10.1155/ 2018/5063185

31. Rayavarapu B, Tallapragada P, Road M (2019) Evaluation of potential probiotic characters of Lactobacillus fermentum. St Cerc St CICBIA 20(2):183-197

32. Dunne C, Collins JK, Shanahan F, O'Sullivan GC, Feeney M, Murphy L, Kiely B, Daly C, O'Halloran S, Fitzgerald G et al (2018) In vitro selection criteria for probiotic bacteria of human origin: correlation with in vivo findings. Am J Clin Nutr 73(2):386s-392s. https://doi.org/10.1093/ajcn/73.2.386s

33. Reuben RC, Roy PC, Sarkar SL, Alam RU, Jahid IK (2019) Isolation, characterization, and assessment of lactic acid bacteria toward their selection as poultry probiotics. BMC Microbiol 19(1):253. https://doi.org/10.1186/s12866-019-1626-0

34. Georgieva R, Danguleva A, Stefanova-Todorova N, Karapetkov N, Rumyan N, Karaivanova E (2016) Cell-surface hydrophobicity and adhesion ability to human epithelial cell line of industrially important lactic acid bacteria and Bifidobacteria. Pap Present Int Sci Conf Probiotics Prebiotics, Budapest (p. 96). IPC2016

35. de Melo Pereira GV, de Oliveira CB, Magalhães-Júnior AI, Thomaz-Soccol V, Soccol CR (2018) How to select a probiotic? A review and update of methods and criteria. Biotechno Adv 36(8):2060-2076. https://doi.org/10.1016/j.biotechadv. 2018.09.003
36. Mahmoudi M, Khomeiri M, Saeidi M, Kashaninejad M, Davoodi H (2019) Study of potential probiotic properties of lactic acid bacteria isolated from raw and traditional fermented camel milk. J Agr Sci Tech-Iran 21(5):1161-1172

37. Valero-cases E, Cerdá-bernad D, Pastor J, Frutos M (2020) Nondairy fermented beverages as potential carriers to ensure probiotics, prebiotics, and bioactive compounds arrival to the gut and their health benefits. Nutrients 12(06):1666. https://doi.org/10. 3390/nu12061666

38. Cissé H, Kagambèga B, Sawadogo A, Tankoano A, Sangaré G, Traoré Y, Ouoba IIL, Savadogo A (2019) Molecular characterization of Bacillus, lactic acid bacteria and yeast as potential probiotic isolated from fermented food. Scientific African 6:e00175. https://doi.org/10.1016/j.sciaf.2019.e00175

39. Mathur H, Beresford TP, Cotter PD (2020) Health benefits of lactic acid bacteria. Nutrients 12:1679. https://doi.org/10.3390/ nu12061679

40. Markowiak P, Ślizewska K (2017) Effects of probiotics, prebiotics, and synbiotics on human health. Nutrients 9(9):1021. https:// doi.org/10.3390/nu9091021

41. Buffie CG, Pamer EG (2014) Microbiota-mediated colonization resistance against intestinal pathogens. Nat Rev Immunol 13(11):790-801. https://doi.org/10.1038/nri3535.Microbiotamediated

42. Shokryazdan P, Faseleh-Jahromi M, Liang JB, Ho YW (2017) Probiotics: from isolation to application. J Am Coll Nutr 36(8):666-676. https://doi.org/10.1080/07315724.2017.1337529

43. Somashekaraiah R, Shruthi B, Deepthi BV, Sreenivasa MY (2019) Probiotic properties of lactic acid bacteria isolated from neera: a naturally fermenting coconut palm nectar. Front Microbiol 10:1382. https://doi.org/10.3389/fmicb.2019.01382

44. Kisan BS, Kumar R, Ashok SP, Sangita G (2019) Probiotic foods for human health: a review. J Pharmacogn Phytochem 8(3):967-971

45. Salvetti E, Harris HMB, Felis GE, O’ Toole PW (2018) Comparative genomics of the genus Lactobacillus reveals robust phylogroups that provide the basis for reclassification. Appl Environ Microbiol 84(17):e00993-e1018. https://doi.org/10.1128/AEM. 00993-18

46. Zheng J, Wittouck S, Salvetti E, Franz CMAB, Harris HMB, Mattarelli P, O'Toole PW, Pot B, Vandamme P, Walter J et al (2020) A taxonomic note on the genus Lactobacillus: description of 23 novel genera, emended description of the genus Lactobacillus Beijerinck 1901, and union of Lactobacillaceae and Leuconostocaceae. Int J of Syst Evol Microbiol 70:2782-2858. https://doi.org/10.1099/ijsem.0.004107

47. Ng SY, Koon SS, Padam BS, Chye FY (2015) Evaluation of probiotic potential of lactic acid bacteria isolated from traditional Malaysian fermented Bambangan (Mangifera pajang). CYTA-J Food 13(4):563-572. https://doi.org/10.1080/19476337.2015. 1020342

48. Evivie SE, Huo GC, Igene JO, Bian X (2017) Some current applications, limitations and future perspectives of lactic acid bacteria as probiotics. Food Nutr Res 61(1):1318034. https://doi. org/10.1080/16546628.2017.1318034

49. WHO (2019) World malaria report 2019. https://www.who.int/ news-room/feature-stories/detail/world-malaria-report-2019 Retived 22nd of May 2020

50. Dawaki S, Al-Mekhlafi HM, Ithoi I, Ibrahim J, Atroosh WM, Abdulsalam AM, Sady H, Elyana FN, Adamu AU, Yelwa SI et al (2016) Is Nigeria winning the battle against malaria? Prevalence, risk factors and KAP assessment among Hausa communities in Kano state. Malar J 15:351. https://doi.org/10.1186/ s12936-016-1394-3

51. Ibrahim BS, Abubakar AA, Bajoga UA, Nguku PM (2017) Evaluation of the malaria surveillance system in Kaduna state, 
Nigeria 2016. International Society in Disiease Surveillance 9(1):e177. http://ojphi.org

52. Crompton PD, Moebius J, Portugal S, Waisberg M, Hart G, Garver LS, Miller LH, Barillas-Mury C, Pierce SK (2014) Malaria immunity in man and mosquito: insights into unsolved mysteries of a deadly infectious disease. Annu Rev Immunol 32(1):157-187. https://doi.org/10.1146/annurev-immunol-032713-120220

53. Mukherjee D, Chora AF, Mota MM (2020) Microbiota, a third player in the host-Plasmodium affair. Trends Parasitol 36(1): 11-18. https://doi.org/10.1016/j.pt.2019.11.001

54. Augustina F, Asamoah KK, Bernard T, Fokuo OM, Wilfred N (2018) Characterization of $\mathrm{T}$ cell activation and regulation in children with asymptomatic Plasmodium falciparum infection. Malar J 17(1):263. https://doi.org/10.1186/s12936-018-2410-6

55. Nlinwe ON, Kusi KA, Adu B, Sedegah M (2018) T-cell responses against Malaria: effect of parasite antigen diversity and relevance for vaccine development. Vaccine 36(17):22372242. https://doi.org/10.1016/j.vaccine.2018.03.023

56. Chuangchaiya S, Jangpatarapongsa K, Chootong P, Sirichaisinthop J, Sattabongkot J, Pattanapanyasat K, Chotivanich K, Troye-Blomberg M, Cui L, Udomsangpetch R (2010) Immune response to Plasmodium vivax has a potential to reduce malaria severity. Clin Exp Immunol 160(2):233-239. https://doi.org/10.1111/j.1365-2249.2009. 04075.x

57. Pleass RJ, Holder AA (2005) Antibody-based therapies for malaria. Nat Rev Microbiol 3(11):893-899. https://doi.org/10. 1038/nrmicro1267

58. Shibui A, Hozumi N, Shiraishi C, Sato Y, Iida H, Sugano S, Watanabe J (2009) CD4+ T cell response in early erythrocytic stage malaria: Plasmodium berghei infection in BALB/c and C57BL/6 mice. Parasitol Res 105(1):281-286. https://doi.org/ 10.1007/s00436-009-1435-8

59. Pérez-Mazliah D, Ng DHL, Freitas do Rosário AP, McLaughlin S, Mastelic-Gavillet B, Sodenkamp J, Kushinga G, Langhorne J, (2015) Disruption of IL-21 Signaling affects T cell-B cell interactions and abrogates protective humoral immunity to malaria. PLoS Pathog 11(3):e1004715. https://doi.org/10.1371/journal. ppat.1004715

60. Gowda DC, Wu X (2018) Parasite recognition and signaling mechanisms in innate immune responses to malaria. Front Immunol 9:3006. https://doi.org/10.3389/fimmu.2018.03006

61. Kusi KA, Manu EA, Gwira TM, Kyei-Baafour E, Dickson EK, Amponsah JA, Remarque EJ, Faber BW, Kocken CHM, Dodoo D et al (2017) Variations in the quality of malaria-specific antibodies with transmission intensity in a seasonal malaria transmission area of Northern Ghana. PLoS ONE 12(9):e0185303. https://doi.org/10.1371/journal.pone.0185303

62. Cui L, Mharakurwa S, Ndiaye D, Rathod PK, Rosenthal PJ (2015) Antimalarial drug resistance: literature review and activities and findings of the ICEMR network. Am J Trop Med Hyg 93(Suppl 3):57-68. https://doi.org/10.4269/ajtmh.15-0007

63. Singh S, Agarwal D, Sharma K, Sharma M, Nielsen MA, Alifrangis M, Singh AK, Gupta RD, Awasthi SK (2016) 4-Aminoquinoline derivatives: synthesis, in vitro and in vivo antiplasmodial activity against chloroquine-resistant parasites. Eur J Med Chem 122:394-407. https://doi.org/10.1016/j.ejmech. 2016.06.033

64. Oyebola KM, Aina OO, Bah MM, Ajibaye S, Correa S, Awandare GA, Amambua-Ngwa A (2018) Assessing naturally acquired immune response and malaria treatment outcomes in Lagos, Nigeria. AAS Open Res 1(0):6. https://doi.org/10. 12688/aasopenres.12828.1

65. Anum D, Kusi KA, Ganeshan H, Hollingdale MR, Ofori MF, Koram KA, Gyan BA, Adu-Amankwah S, Badji E, Huang J et al (2015) Measuring naturally acquired ex vivo IFN- $\gamma$ responses to Plasmodium falciparum cell-traversal protein for ookinetes and sporozoites (CelTOS) in Ghanaian adults. Malar J 14:20. https:// doi.org/10.1186/s12936-014-0539-5

66. Kengne-Ouafo JA, Sutherland CJ, Binka FN, Awandare GA, Urban BC, Dinko B (2019) Immune responses to the sexual stages of Plasmodium falciparum parasites. Front Immunol 10(2):136. https://doi.org/10.3389/fimmu.2019.00136

67. Doumbo OK, Niaré K, Healy SA, Sagara I, Duffy PE (2018) Malaria transmission-blocking vaccines: present status and future perspectives. In Towards malaria elimination - a leap forward. S Manguin ed (IntechOpen Ltd, UK), pp. 363-385 https://doi.org/ 10.5772/intechopen.77241

68. Dong Y, Manfredini F, Dimopoulos G (2009) Implication of the mosquito midgut microbiota in the defense against malaria parasites. PLoS Pathog 5(5):e1000423. https://doi.org/10.1371/journal. ppat. 1000423

69. Akorli J, Namaali PA, Ametsi GW, Egyirifa RK, Pels NAP (2019) Generational conservation of composition and diversity of field-acquired midgut microbiota in Anopheles gambiae (sensu lato) during colonization in the laboratory. Parasit Vectors 12(1):27. https://doi.org/10.1186/s13071-019-3287-0

70. Saraiva RG, Dimopoulos G (2020) Bacterial natural products in the fight against mosquito-transmitted tropical diseases. Nat Prod Rep 37(3):338-354. https://doi.org/10.1039/c9np00042a

71. Ngwa CJ, Pradel G (2015) Coming soon: probiotics-based malaria vaccines. Trends Parasitol 31(1):2-4. https://doi.org/10. 1016/j.pt.2014.11.006

72. Yilmaz B, Portugal S, Tran TM, Gozzelino R, Ramos S, Gomes J, Regalado A, Cowan PJ, D’Apice AJF, Chong AS et al (2014) Gut microbiota elicits a protective immune response against malaria transmission. Cell 159(6):1277-1289. https://doi.org/ 10.1016/j.cell.2014.10.053

73. Cabezas-Cruz A, Valdés JJ, de la Fuente J (2016) Control of vector-borne infectious diseases by human immunity against $\alpha$-Gal. Expert Rev Vaccines 15(8):953-955. https://doi.org/10. 1080/14760584.2016.1181547

74. Cabezas-Cruz A, de la Fuente J (2017) Immunity to $\alpha$-Gal: The opportunity for malaria and tuberculosis control. Front Immunol 8:1733. https://doi.org/10.3389/fimmu.2017.01733

75. Abagna HB, Acquah FK, Okonu R, Aryee NA, Theisen M, Amoah LE (2018) Assessment of the quality and quantity of naturally induced antibody responses to EBA175RIII-V in Ghanaian children living in two communities with varying malaria transmission patterns. Malar J 17(1):14. https://doi.org/10.1186/ s12936-017-2167-3

76. Stough JMA, Dearth SP, Denny JE, LeCleir GR, Schmidt NW, Campagna SR, Wilhelm SW (2016) Functional characteristics of the gut microbiome in C57BL/6 mice differentially susceptible to Plasmodium yoelii. Front Microbiol 7:1520. https://doi.org/ 10.3389/fmicb.2016.01520

77. Travers M-A, Florent I, Kohl L, Grellier P (2011) Probiotics for the control of parasites: an overview. J Parasitol Res 2011:610769. https://doi.org/10.1155/2011/610769

78. Taniguchi T, Miyauchi E, Nakamura S, Hirai M, Suzue K, Imai T, Nomura T, Handa T, Okada H, Shimokawa C et al (2015) Plasmodium berghei ANKA causes intestinal malaria associated with dysbiosis. Sci Rep 5:15699. https://doi.org/10.1038/srep15699

79. Cabezas-Cruz A, Mateos-Hernández L, Alberdi P, Villar M, Riveau G, Hermann E, Schacht AM, Khalife J, Correia-Neves M, Gortazar C, de la Fuente J (2017) Effect of blood type on anti-a-Gal immunity and the incidence of infectious diseases. Exp Mol Med 49(3):e301. https://doi.org/10.1038/emm.2016.164

80. Cabezas-Cruz A, Mateos-Hernández L, Pérez-Cruz M, Valdés JJ, de Mera IGF, Villar M, de la Fuente J (2015) Regulation of the immune response to $\alpha$-Gal and vector-borne diseases. Trends Parasitol 31(10):470-476. https://doi.org/10.1016/j.pt.2015.06.016 
81. de Coelho ZB, A, Mourão LC, Rodrigues BCM, CardosoOliveira GP, Hincapie R, Sanhueza-Chavez C, Finn M, Fontes CJF, Marques AF, Braga ÉM, (2019) Preliminary assessment of anti- $\alpha-G a l$ IgG and IgM levels in patients with patent Plasmodium vivax infection. Mem I Oswaldo Cruz 114:e190145. https:// doi.org/10.1590/0074-02760190145

82. Galili U (2019) Evolution in primates by "catastrophic-selection" interplay between enveloped virus epidemics, mutated genes of enzymes synthesizing carbohydrate antigens, and natural anticarbohydrate antibodies. Am J Phys Anthropol 168(2):352-363. https://doi.org/10.1002/ajpa.23745

83. Steinke JW, Platts-Mills TAE, Commins SP (2016) Alpha Gal story: lessons learned from connecting the dots. J Allergy Clin Immunol 135(3):589-597. https://doi.org/10.1016/j.jaci.2014.12.1947

84. Galili U (2005) The $\alpha$-gal epitope and the anti-Gal antibody in xenotransplantation and in cancer immunotherapy. Immunol Cell Biol 83(6):674-686. https://doi.org/10.1111/j.1440-1711.2005. 01366.x

85. Cabezas-Cruz A, de la Fuente J (2017) Immunity to $\alpha-G a l:$ toward a single-antigen pan-vaccine to control major infectious diseases. ACS Cent Sci 3(11):1140-1142. https://doi.org/10. 1021/acscentsci.7b00517

86. Galili U (2020) Human natural antibodies to mammalian carbohydrate antigens as unsung heroes protecting against past, present, and future viral infections. Antibodies 9(2):25. https://doi. org/10.3390/antib9020025

87. Yooseph S, Kirkness EF, Tran TM, Harkins DM, Jones MB, Torralba MG, O'Connell E, Nutman TB, Doumbo S, Doumbo OK et al (2015) Stool microbiota composition is associated with the prospective risk of Plasmodium falciparum infection. BMC Genomics 16(1):631. https://doi.org/10.1186/s12864-015-1819-3

88. Mackowiak PA (2013) Recycling Metchnikoff: probiotics, the intestinal microbiome and the quest for long life. Front Public Health 1:52. https://doi.org/10.3389/fpubh.2013.00052

89. Martín R, Langella P (2019) Emerging health concepts in the probiotics field: streamlining the definitions. Front Immunol 10:1047. https://doi.org/10.3389/fmicb.2019.01047

90. Pandey KR, Naik SR, Vakil BV (2015) Probiotics, prebiotics and synbiotics - a review. J Food Sci Technol 52(12):7577-7587. https://doi.org/10.1007/s13197-015-1921-1

91. George-Kerry R, Patra JK, Gouda S, Park Y, Shin HS, Das G (2018) Benefaction of probiotics for human health: a review. J Food Drug Anal 26(3):927-939. https://doi.org/10.1016/j.jfda. 2018.01.002

92. Maegraith BG, Deegan T, Jones ES (1952) Suppression of malaria (P. berghei) by milk. Br Med J Dec 27:1382-1384.

93. Zimmermann P, Curtis N (2020) Breast milk microbiota: a complex microbiome with multiple impacts and conditioning factors. J Infection 81:17-47. https://doi.org/10.1016/j.jinf.2020.01.023

94. Lokki IA, Järvelä I, Israelsson E, Maiga B, Troye-Blomberg Marita Dolo A, Doumbo OK, Meril S, Holmberg V (2011) Lactase persistence genotypes and malaria susceptibility in Fulani of Mali. Malar J 10(9):157. https://doi.org/10.1136/gut.37.1.157

95. Bordon Y (2015) Microbiota: gut bacteria cross malaria. Nat Rev Immunol 15(1):1. https://doi.org/10.1038/nri3796

96. Chang C, Kao C (2019) Current understanding of the gut microbiota shaping mechanisms. J Biomed Sci 26(1):59. https://doi. org/10.1186/s12929-019-0554-5

97. Spencer SP, Fragiadakis GK, Sonnenburg JL (2019) Pursuing human-relevant gut microbiota-immune interactions. Immunity 51(2):225-239. https://doi.org/10.1016/j.immuni.2019.08.002
98. Derrien M, Alvarez A, De VWM (2019) The gut microbiota in the first decade of life. Trends Microbiol 27(12):997-1010. https://doi.org/10.1016/j.tim.2019.08.001

99. Mandal RK, Denny JE, Waide ML, Li Q, Bhutiani N, Anderson CD, Baby BV, Jala VR, Egilmez NK, Schmidt NW (2020) Temporospatial shifts within commercial laboratory mouse gut microbiota impact experimental reproducibility. BMC Biol 18(1):83. https://doi.org/10. 1186/s12915-020-00810-7

100. Waide ML, Schmidt NW (2020) The gut microbiome, immunity, and Plasmodium severity. Curr Opin Microbiol 58:56-61. https:// doi.org/10.1016/j.mib.2020.08.006

101. Omeiza FO, Ademowo GO, Ayeni FA (2020) Evaluation of in vivo anti-malarial potential of omidun obtained from fermented maize in Ibadan. Nigeria Malar J 19(1):414. https://doi.org/10. 1186/s12936-020-03486-0

102. Gozar MM, Price VL, Kaslow DC (1998) Saccharomyces cerevisiae-secreted fusion proteins pfs 25 and pfs 28 elicit potent Plasmodium falciparum transmission-blocking antibodies in mice. Infect Immun 66(1):59-64. https://doi.org/10.1128/IAI.66.1. 59-64.1998

103. Zemedkun D, Alaparmak H, Morris F, Omar S, Khan S, Park D, Panjaitan J, Palma N, Apte S (2001) Expression of an antimalarial peptide by plasmid transfected Yogurt bacteria I: feasibility, experimental design and measurement. J High School Sci 1:43

104. Ippolito MM, Denny JE, Langelier C, Sears CL, Schmidt NW (2018) Malaria and the microbiome: a systematic review. Clin Infect Dis 67(12):1831-1839. https://doi.org/10.1093/cid/ciy374

105. Lee MSJ, Coban C (2020) Mucosal vaccine for malaria. In: Mucosal vaccines (second edition). Innovation for Preventing Infectious Diseases 2020:831-840. https://doi.org/10.1016/ B978-0-12-811924-2.00049-3

106. Pope JL, Tomkovich S, Jobin C (2020) Influence of commensal microbiota and metabolite for mucosal immunity. In: Mucosal vaccines (second edition). Innovation for Preventing Infectious Diseases 2020:143-164. https://doi.org/10.1016/B978-0-12811924-2.00009-2

107. Gunasekaran B, Gothandam KM (2020) A review on edible vaccines and their prospects. Braz J Med Biol Res 53(2):e8749. https://doi.org/10.1590/1414-431x20198749

108. Martinez-Gomez F, Ixta-Rodriguez O, Aguilar-Figueroa B, Hernandez-Cruz R, Monroy-Ostria A (2006) Lactobacillus casei ssp. rhamnosus enhances non-specific protection against Plasmodium chabaudi AS in mice. Salud Publica Mex 48(6):498-503.

109. Serirom S, Raharjo WH, Chotivanich K, Loareesuwan S, Kubes P, Ho M (2003) Anti-adhesive effect of nitric oxide on Plasmodium falciparum cytoadherence under flow. Am J Pathol 162(5):1651-1660. https://doi.org/10.1016/S0002-9440(10) 64299-X

110. Balmer P, Phillips HM, Maestre AE, McMonagle FA, Phillips RS (2000) The effect of nitric oxide on the growth of Plasmodium falciparum, $P$. chabaudi and $P$. berghei in vitro. Parasite Immunol 22(2):97-106. https://doi.org/10.1046/j.1365-3024. 2000.00281.x

111. Lora VH, Dan RL, Andrew JM (2012) Interactions between the microbiota and the immune system. Science 336(6086):12681273. https://doi.org/10.1126/science. 1223490

Publisher's Note Springer Nature remains neutral with regard to jurisdictional claims in published maps and institutional affiliations. 